\title{
The Influence of Climatic and Edaphic Conditions on the Development of Thuja occidentalis 'Smaragd' Under the Urban Conditions of a Large City
}

\author{
Volodymyr P. Kycheryavyi ${ }^{1}$, Vasyl Popovych ${ }^{2 *}$, Volodymyr S. Kycheryavyi', \\ Oleksandra Dyda ${ }^{3}$, Taras Shuplat ${ }^{2}$, Pavlo Bosak ${ }^{2}$ \\ 1 Educational and Scientific Institute of Forestry and Landscape Management, Ukrainian National Forestry \\ University, General Chyprynka Str. 103, Lviv, 79000, Ukraine \\ 2 Institute of Civil Protection, Lviv State University of Life Safety, Kleparivska Str. 35, Lviv, 79007, Ukraine \\ ${ }^{3}$ Institute of Architecture and Design, Lviv Polytechnic National University, S. Bandera Str. 12, Lviv, 79013, \\ Ukraine \\ *Corresponding author's e-mail: popovich2007@ukr.net
}

\begin{abstract}
The negative effects of the urban environment on the morphological and physiological states of Thuja occidentalis 'Smaragd' have been investigated. For comparison, two plots were selected for the cultivation of eastern arborvitae cultivars: one in a public garden (the control plot) and the other one in street planting with its positive vertical temperature gradient associated with overheating and dehydration of the soil. This situation had a negative impact on the biometric and physiological parameters of the plants, and, in the end, the level of their vitality. If, under optimal growth conditions, the vertical temperature gradient is negative (the air temperature in the crown is higher and the soil temperature in the rhizosphere zone is lower), the physiological processes in Thuja ocidentalis 'Smaragd' (transpiration, water-holding capacity) proceed in a normal mode. A change in the temperature regime (soil temperature is higher than the air temperature in the crown), under the conditions of a positive temperature gradient, leads to negative consequences: the morphological structure of plants changes (the growth of the apical and side shoots slows down, the number of needles increases, the lower parts of the trunks become bared, the length and volume of the crown are reduced), also physiological processes are disturbed - moisture deficiency increases, water holding capacity decreases, the pigment composition of needles changes towards decreasing the amount of chlorophylls $(\mathrm{a}+\mathrm{b})$ and carotenoids. A decrease in the vitality level of the study plants with a positive temperature gradient was confirmed by the vitality indices $R_{f d}$ established by means of the fluorescence method (negative gradient 0.64 ; positive gradient 0.33 ).
\end{abstract}

Keywords: climate, edaphotop, Thuja ocidentalis 'Smaragd', environmental landscaping

\section{INTRODUCTION}

Urbanization processes that are extremely intensive in large cities make the climatopes and edaphotopes of urban ecosystems drier, which often prevents the growth of the trees adapted to wetter conditions of the natural growth range (Kycheryavyi V.P. 2001, Kycheryavyi V.S. 2015). The study on the adaptation of introduced species that grow in a large city, such as Lviv, showed that the success of the introduction of trees in landscaping depends on the edapho-climatic ecological-phytocoenotic belts (EFB), into which the urban territory is divided (suburban forest park park - public garden - street).

Lviv is the center of urban agglomeration with a population of over one million. The city, which has an almost 800-year history, is located on the Main European watershed. Due to its geographical location, it is under the simultaneous influence of the air masses of Eurasia and the Atlantic Ocean. The natural and climatic conditions 
contribute to the widespread introduction of nonindigenous species into the city's landscaping, thus enriching the species diversity. The largest number of species is represented by the European-Siberian (139) and East Asian botanical-andgeographical zones, whereas the Mediterranean group is less represented (42). About $15 \%$ of the introduced species come from North America, in particular the Atlantic subarea is represented by 49 , and the Pacific area - by 72 species. Ornamental cultivars are very widely represented in the urban landscaping system. However, a high level of vitality of the introduced species is observed only under the favorable conditions of botanical gardens, arboretum and city parks (EFB II). Under the urban conditions of streets and squares, densely built-up areas, industrial zones (EFB IV), a different degree of suppression of woody plants, their premature aging and dying off are observed (Kycheryavyj V.P. et al. 2018).

In a large city, introduced species (exotic species) often act as bio-indicators of the ecological state of the urban environment. We were convinced of this by conducting comprehensive studies of the vitality of Thuja occidentalis 'Smaragd', an ornamental form that is widespread in Ukraine's landscaping today.

Thuja occidentalis 'Smaragd' is a cultivar with a very expressive conical crown shape and dark green color of needles which was bred in Denmark (breeder D.T. Poulsen, Kvistgaard nursery) in 1950. Since the late 1980s, it has been widely used in landscaping of Ukrainian settlements, especially in the western regions which are similar in climate to the homeland of Thuja - the Atlantic coast of North America. The cultivar prefers fertile loamy and sandy loamy soils and well-illuminated growth conditions, which contributes to enhancing its ornamental qualities, although it also tolerates partial shade. Seed production is weak. Today, Thuia is widely used in ornamental gardens, alleys, hedges and various composition groups.

According to the observation, Thuja oscidentalis 'Smaragd' does not tolerate the urban xerophytic conditions of large cities with high levels of contamination and soil compaction. Under these conditions, the cultivar gives small increments of apical and side shoots, reduces the natural color saturation of the needles, the level of ornamental quality and often dies out (Sarbaeva et al. 2002). However, only by external signs, is it difficult to determine the level of plant vitality; that is why the chlorophyll fluorescence method was used to determine the viability index (Kapustyanyk and Mokryi 2004, Kycheryavyi V.S. 2012).

\section{MATERIALS AND METHODS}

The aim of the study was to determine the parameters of negative urban influences on urban climatopes and edaphotopes of Thuja oscidentalis 'Smaragd' habitat and its vitality, which is manifested in the changes in its morpho-physiological states. The idea of the study was a comprehensive assessment of the vitality of a particular Thuja ocidentalis 'Smaragd' cultivar, based on simultaneous studies of the morphological and physiological conditions of the plants. The object of the study is a row, even-aged (10 years) planting of Thuja oscidentalis 'Smaragd' cultivars under different edapho-climatic conditions.

In order to determine the vertical temperature gradient of the environment under the influence of which the study plants are situated, the Radchenko (1966) method was used, according to which the temperatures of the soil (the root system zone) and the air in the crown of the trees were measured simultaneously. The vertical temperature gradient indices were determined by the formula:

$$
T_{v g}= \pm\left(t_{n}-t_{k}\right),
$$

where: $T_{v g}$ is the temperature vertical gradient of the environment, ${ }^{\circ} \mathrm{C}$;

$t_{n}$ is the air temperature at the plant crown level, ${ }^{\circ} \mathrm{C}$;

$t_{k}$ is the temperature in the root system zone, ${ }^{\circ} \mathrm{C}$.

Temperature horizontal gradients of the environment represent the temperature difference between various points of soil temperature measurement at a horizontal level (near the trunk and outside the planting). This indicator was calculated by the formula:

$$
T_{h g}= \pm\left(t_{2}-t_{1}\right) \text {, }
$$

where: $T_{h g}$ is the temperature horizontal gradient of the air, ${ }^{\circ} \mathrm{C}$;

$t_{t}$ and $t$, is the temperature difference between the measurement points (temperature mosaic), ${ }^{\circ} \mathrm{C}$.

Three-fold repetition of experiments showed that the temperature gradient can be negative when the temperature of the air or the aboveground organs of the plant is higher than the temperature of 
the soil or root system. Positive - when the temperature of the air (or the aboveground part of the plant) is lower than the temperature of the soil (or root system). The gradient can also be zero when the air temperature of the crown air and in the soil is the same and the difference between these parameters is not apparent.

The assessment of the plant vitality was made according to the method of Sarbaeva and Voskresenskaya (2005). With this method, the following morphological indicators were determined: plant height, trunk diameter, crown length and diameter, the number of second-order shoots (live and dying terminal and side shoots), annual shoot increment and the number of needles per $10 \mathrm{~cm}$ of shoot length. According to the morphological parameters, the Thuja plants were divided into three groups of vitality: healthy, suppressed and strongly suppressed (Sarbaeva et al. 2002).

Field moisture and water deficiency were determined by using the method of Rudyshyn and Kuryata (2004). According to this method, needles were cut from different layers of a tree, placed in absolutely dry boxes, covered with a lid and were immediately weighed. Then, the needles were taken out, immersed into water pans, mixed up and left for two hours to saturate the tissue with moisture. After that, the needles were taken out and laid out on filter paper which simultaneously covered the samples from above being gently pressed to the needles in order to absorb moisture from their surface as much as possible. Subsequently, the needles were again placed in the boxes, closed and weighed. The obtained data made it possible to calculate the water deficiency $\left(W_{d}\right)$ index of the trees grown under different environmental conditions. The calculation was carried out according to the following formula:

$$
W_{d}=\frac{M_{2}-M_{1}}{M_{2}} \cdot 100 \%,
$$

where: $M_{1}$ is the sample weight prior to saturation, $\mathrm{g}$;

$M_{2}$ is the sample weight after saturation, $\mathrm{g}$.

The ratio of chlorophylls $a$ and $b$ and carotenoids was determined on the basis of the chromatographic method according to Bessonova (2006). The studies began in 2010, when the plants were 9 years old. Their average height was $159.4 \mathrm{~cm}$, in 2011 it reached $182.5 \mathrm{~cm}$, whereas in $2012-205 \mathrm{~cm}$. In October 2013, the last biometric measurements of growth were carried out and the vitality of the study plants was determined.
Plant vitality index $\left(R_{f d}\right)$ was determined on the basis of comparative measurements of photosynthesis fluorescence kinetics as the difference between the values of maximum $\left(F_{m}\right)$ and background $\left(F_{o}\right)$ fluorescence divided by $F_{m}$ by the formula:

$$
R_{f d}=\frac{F_{m}-F_{o}}{F_{m}} .
$$

\section{RESULTS AND DISCUSSION}

Adverse edapho-climatic conditions of a large city affect the ontogenesis of plants and their vitality (Sarbaeva et al. 2002). The increasing anthropogenic load complicates the life processes and often leads to disruption of homeostasis of plants, forcing them to adapt their structure and functions to new conditions of existence, to include adaptive mechanisms.

It is especially hard for coniferous species to live under urban conditions. These species, despite their high ornamental qualities, due to their high sensitivity to pollutants and xerophytes of the urban environment, are not well represented in the urban landscape. However, some coniferous species are relatively resistant to urban conditions, among them is American arborvitae (Thuja occidentalis) and its numerous ornamental cultivars. These plants possess not only high aesthetic qualities, but, in comparison with other conifers, they resist the effects of overheating and contamination of the habitat to the highest degree.

\section{Features of morphogenesis and growth energy of Thuja occidentalis 'Smaragd'}

A negative temperature gradient was found to be characteristic of the study specimens growing in the garden. At the same time, in the plants growing near the sidewalk, at the beginning of the summer season and at the end of summer, the temperature gradient tends to "zero" $(-1.8-$ $2.0^{\circ} \mathrm{C}$ ), and in the summer (July, August) changes to positive $\left(1.2-0.8^{\circ} \mathrm{C}\right)$.

This phenomenon is explained by the fact that the edaphic conditions (soil density and moisture content) in street planting are xerophytic, since the temperature of compacted soil due to increased thermal conductivity is much higher than that of the loose soil of the public garden. The soil moisture content is also much lower. 
The results of the study on the edapho-climatic conditions of the Thuja occidentalis growth during the growing season are shown in Table 1.

It was found (Kycheryavyi V.P., 2001) that higher plants are adapted to a negative temperature gradient, that is, to such a temperature regime in which the temperature of the soil on a sunny summer day (during the period of active growth of plants) should be at least $3-8^{\circ} \mathrm{C}$ lower than the air temperature. This requirement cannot be ignored, since such a situation contributes to the premature aging and, subsequently, the death of the plant. The vertical temperature gradient, which rises above $4-5^{\circ} \mathrm{C}$, disrupts the course of metabolic processes and leads to intoxication of the plant organism (Radchenko 1966).

With regard to the horizontal temperature gradient, it is manifested when the temperature of the point that is compared with the starting point is higher, and vice versa, the gradient will be positive when the temperature of the second measuring point is lower than that of the starting point. A zero gradient was observed when there was no temperature difference between the two measurement points. The horizontal temperature gradient (both soil and air) in the arborvitae planting that grows along the sidewalk is negative (positive) and harmful to the plants. This is reflected in dependences (5) and (6):

$$
\begin{aligned}
& T_{s g}=21.8^{\circ} \mathrm{C}-15.9^{\circ} \mathrm{C}=+5.9^{\circ} \mathrm{C}, \\
& T_{a g}=22.6^{\circ} \mathrm{C}-20.5^{\circ} \mathrm{C}=+2.1^{\circ} \mathrm{C} .
\end{aligned}
$$

where: $T_{s g}$ - soil temperature gradient, ${ }^{\circ} \mathrm{C}$;

$T_{a g}^{s g}$ - air temperature gradient, ${ }^{\circ} \mathrm{C}$.

This trend is also observed during the period of five months, which is reflected in Figure 1.
The most distinctly negative horizontal temperature gradient appeared in July - September, when it is the lowest. During this period, the levels of soil moisture is the lowest and both gradients, vertical and horizontal, are negative and correlate with each other. This means that plants experience the greatest negative impact on their vitality, which is manifested in their morphophysiological states and is confirmed by biometric measurements.

According to the state of morphological indicators, three groups of Thuja trees vitality were distinguished: healthy, suppressed and strongly suppressed (Table 2).

The biometric indicators were measured and the visual inspection of the trees in the row planting formed the basis for the analysis and differentiation of the plants by vitality classes:

Class I - healthy trees: no signs of damage, the crown is well-developed, thick, bright green, and symmetrical. The length of the crown is 212 $\mathrm{cm}$ and its lower shoots touch the surface of the earth. The crown width is $70 \mathrm{~cm}$. There are no dead and dying shoots. The diameter of the trunk is $2.5 \mathrm{~cm}$. The top, which is formed by the increment of the current year, is pointed, its length is $21.7 \mathrm{~cm}$. The increase in side shoots is $6.1 \mathrm{~cm}$. The crowns are not closed, the distance between individual trees is $40 \mathrm{~cm}$. The number of needles per $10 \mathrm{~cm}$ of shoot length is $87 \mathrm{pcs}$. Seasonal seed production is weak.

Class II - suppressed trees: notable damage to shoots, needles and trunk. The crown is somewhat flattened, brownish green, asymmetrical. The length of the crown is $186 \mathrm{~cm}$, the lower part of the trunk to a height of $20 \mathrm{~cm}$ is bare. The

Table 1. Indices of edapho-climatic conditions and plant growth in Thuja occidentalis 'Smaragd' planting (row

\begin{tabular}{|c|c|c|c|c|c|c|c|c|c|c|}
\hline $\begin{array}{l}\text { Year } \\
2013 \text {, } \\
\text { months }\end{array}$ & $\begin{array}{c}\text { Soil } \\
\text { tempe- } \\
\text { rature, }{ }^{\circ} \mathrm{C}\end{array}$ & $\begin{array}{c}\text { Soil } \\
\text { moisture, } \\
\%\end{array}$ & $\begin{array}{l}\text { Soil density at } \\
\text { the depth of } \\
\text { rhizosphere } \\
\mathrm{kg} / \mathrm{cm}^{2}\end{array}$ & $\begin{array}{c}\text { Air } \\
\text { temperature } \\
\text { at the top of } \\
\text { the crown, }{ }^{\circ} \mathrm{C}\end{array}$ & $\begin{array}{c}\text { Relative } \\
\text { air } \\
\text { humidity, } \\
\%\end{array}$ & $\begin{array}{l}\text { Wind } \\
\text { speed, } \\
\mathrm{m} / \mathrm{s}\end{array}$ & $\begin{array}{c}\text { Vertical } \\
\text { temperature } \\
\text { gradient, }{ }^{\circ} \mathrm{C}\end{array}$ & $\begin{array}{c}\text { Average } \\
\text { plant height } \\
\text { as of } 1 \text { Oct. } \\
2013, \mathrm{~cm}\end{array}$ & $\begin{array}{c}\text { Annual } \\
\text { growth } \\
\text { of apical } \\
\text { shoots, cm }\end{array}$ & $\begin{array}{c}\text { Annual } \\
\text { increment } \\
\text { of side } \\
\text { shoots, cm }\end{array}$ \\
\hline \multirow{2}{*}{ V } & 14.2 & 79.4 & 21.2 & 0.7 & 72.2 & 14.2 & -3.8 & 196.1 & 2.7 & 1.0 \\
\hline & 18.3 & 78.1 & 27.3 & 2.5 & 64.7 & 17.3 & -2.0 & 182.1 & 2.0 & 0.5 \\
\hline \multirow{2}{*}{ VI } & 16.3 & \multirow{2}{*}{$\begin{array}{l}73.4 \\
69.5 \\
\end{array}$} & 21.9 & 0.5 & 69.3 & 14.5 & -5.1 & 201.0 & 4,9 & 1.5 \\
\hline & 20.5 & & 28.0 & 2.0 & 65.0 & 18.3 & -2.0 & 185.3 & 3.5 & 0.5 \\
\hline \multirow{2}{*}{ VII } & 17.0 & 69.8 & 22.2 & 0.5 & 71.4 & 15.3 & -4.8 & 206.2 & 3.5 & 1.5 \\
\hline & 25.5 & 65.7 & 29.1 & 1.9 & 61.2 & 18.7 & +1.2 & 188.8 & 2.0 & 0.7 \\
\hline \multirow{2}{*}{ VIII } & 16.7 & 68.3 & 23.4 & 0.2 & 69.4 & 15.3 & -5.4 & 211.1 & 35 & 1.0 \\
\hline & 25.3 & 55.9 & 31.0 & 2.1 & 60.1 & 19.1 & +0.8 & 192.0 & 4.3 & 0.7 \\
\hline \multirow{2}{*}{ IX } & 15.4 & 67.8 & 23.0 & 0.5 & 74.3 & 15.3 & -3.5 & 215.1 & 4.9 & 1.0 \\
\hline & 19.5 & 49.4 & 29.5 & 2.3 & 70.2 & 19.1 & -1.8 & 195.0 & 1.0 & 0.2 \\
\hline \multirow{2}{*}{$\begin{array}{l}\text { Annual } \\
\text { average }\end{array}$} & 14.8 & 71.3 & 20.5 & 0.48 & 71.3 & 0.48 & -4.5 & 204.6 & 19.5 & 6.0 \\
\hline & 18.4 & 61.3 & 21.3 & 2.16 & 64.2 & 2.16 & -3.8 & 187.8 & 12.8 & 2.1 \\
\hline
\end{tabular}
planting in Acad. S. Yefremov street) 


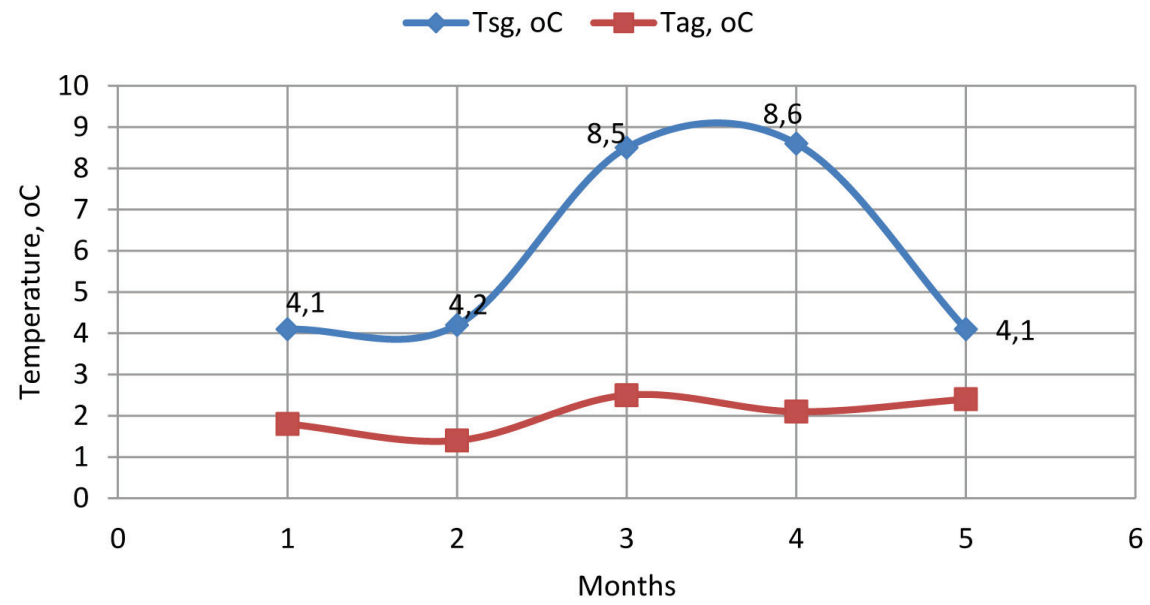

Fig. 1. Horizontal temperature gradients of the soil and air of the Thuja occidentalis 'Smaragd' during the growing season

Table 2. Biometric indicators of the morphological structure of Thuja occidentalis 'Smaragd' individuals and their level of vitality

\begin{tabular}{|c|c|c|c|c|}
\hline \multirow{2}{*}{\multicolumn{2}{|c|}{ Morphological indicators }} & \multicolumn{3}{|c|}{ Vitality classes } \\
\hline & & Healthy & Suppressed & Strongly suppressed \\
\hline \multicolumn{2}{|c|}{ Height, m } & $2.15^{ \pm 0.07}$ & $1.95^{ \pm 0.05}$ & $1.85^{ \pm 0.03}$ \\
\hline \multicolumn{2}{|c|}{ Trunk diameter at a height of $1.3 \mathrm{~m}, \mathrm{~cm}$} & $2.5^{ \pm 0.05}$ & $2.4^{ \pm 0.03}$ & $2.4^{ \pm 0.01}$ \\
\hline \multirow{2}{*}{ Crown } & Length, m & $2.12^{ \pm 0.1}$ & $1.86^{ \pm 0.05}$ & $1.48^{ \pm 0,03}$ \\
\hline & Diameter, $\mathrm{m}$ & $0.7^{ \pm 0.05}$ & $0.5^{ \pm 0.05}$ & $0.4^{ \pm 0,03}$ \\
\hline \multicolumn{2}{|c|}{ Bare-staked lower part of the trunk, $\mathrm{cm}$} & $3.0^{ \pm 0.3}$ & $9.0^{ \pm 0.5}$ & $30.0^{ \pm 0.5}$ \\
\hline \multicolumn{2}{|c|}{ Growth of apical shoot, $\mathrm{cm}$} & $21.7^{ \pm 0.7}$ & $16.3^{ \pm 0.5}$ & $12.4^{ \pm 0.3}$ \\
\hline \multicolumn{2}{|c|}{ Growth of side shoots, $\mathrm{cm}$} & $6.1^{ \pm 0.5}$ & $3.2^{ \pm 0.3}$ & $2.5^{ \pm 0.1}$ \\
\hline \multicolumn{2}{|c|}{ The number of needles per $10 \mathrm{~cm}$ of shoot length } & $87 \pm 5$ & $102^{ \pm 7}$ & $99 \pm 5$ \\
\hline
\end{tabular}

trunk diameter is $2.4 \mathrm{~cm}$. The increment of apical shoots is $16.3 \mathrm{~cm}$, of side shoots $-3.2 \mathrm{~cm}$. The number of needles per $10 \mathrm{~cm}$ of shoot length is 102 pcs. Seeds are plentiful.

Class III - strongly suppressed trees: the crown is flattened to the middle, visible damage to shoots, needles and bark of the trunk. The needles turn brownish yellow. The branches on the trunk are located close to each other, which indicates a weak growth rate, the trunk is bare from below to a height of $50 \mathrm{~cm}$. The bark in the bare part of the trunk and at the base of the lower shoots of the second order is noticeably scaly, the increment of apical shoots is $12.4 \mathrm{~cm}$, of side shoots $-2.5 \mathrm{~cm}$, the number of needles per $10 \mathrm{~cm}$ of shoot is 105 pcs. Seeds are plentiful.

\section{Peculiarities of the physiological states of Thuja occidentalis 'Smaragd'}

The studies were carried out in two directions: the peculiarities of the water regime and the ratio of pigments of plant plastids under various growth conditions.

Since the water regime is one of the most important processes in plant life, comparative studies of its state were carried out in the individuals of Thuja ocidentalis 'Smaragd' which grow under good conditions of a public garden and unfavorable ones - in the street.

Despite the fact that in coniferous species, compared to deciduous, the water regime is more balanced, under the conditions of dry summer and atmospheric pollution, the balance is sharply disturbed and it is very difficult for coniferous trees to withstand these stressful situations. Thuja occidentalis and some of its ornamental forms seem to tolerate this situation, but this is reflected in their general condition, which is manifested in a sharp decline in vitality and ornamental qualities of the plants.

For research, we took the samples of shoots located in the center of the crown on the south side, where the needles transpire more intensively. 
The studies on the seasonal dynamics of the water-holding capacity of Thuja occidentalis 'Smaragd' needles under the conditions of a public garden and street planting revealed the different nature of the water regime. The greatest water losses in the tissue of Thuja needles are observed in the spring (April, May). This is due to the fact that in spring, with the beginning of shoot growth, active metabolic processes occur which are accompanied by an increased content of free water and a low water-holding capacity of tissues. In summer (June-August), the water-holding capacity exhibits some fluctuations and sharply decreases at the end of the growing season. In the street planting, compared to the garden, high water-holding capacity is manifested in early summer (June) and autumn (September) (Fig. 2).

As it turned out, the water content in the plants changes throughout the growing season due to dehydration of needles with increasing water deficiency. It is especially pronounced under the arid conditions of the street and is one of the most important causes of the plant development suppression. In this regard, the state of Thuja ocidentalis 'Smaragd' individuals was investigated depending on the level of field moisture in the soil and the ability to hold water with the needle tissue.

As it is known, with moderate transpiration and a satisfactory flow of water from the soil, a normal, favorable water balance is observed in plants. Under natural conditions, according to literature (Rudyshyn and Kuryata 2004), there is no water shortage in needles. Water deficiency in the range of $10-13 \%$ usually does not harm the plant.

A comparative analysis of soil moisture and water deficiency in needles in the public garden and in the street revealed a direct correlation between arid soil conditions and a lack of moisture in the needle tissue (Fig. 3).

The most difficult conditions for the life of plants, which are manifested in water deficiency, are observed in the mid-summer, when the level of xerophytization is the highest.

\section{Pigment content in the needles of Thuja occidentalis 'Smaragd'}

The plant pigment composition is largely influenced by urban factors, as confirmed by the study. For this purpose, the samples of needles at the end of the growing season were taken to analyze the content and ratio of chlorophylls and carotenoids.

As it turned out, the quantitative composition of pigments in needles of plants depends on the growth conditions (Table 3 ). The highest content of chlorophylls $a$ and $b$ was found in the individuals that grow under optimal conditions of the public garden. At the same time, in the individuals that grow in the area of street planting, the total amount of chlorophylls $a$ and $b$ is $25 \%$ less than that in the public garden individuals $(0.73 \mathrm{mg} / \mathrm{g}$, and the sum of chlorophyll $a+b$ is $2.08 \mathrm{mg} / \mathrm{g}$. As for the ratio of carotenoids, in the individuals that grow in the street, their amount is much smaller than in individuals of the public garden ( 3.75 versus $3.12 \mathrm{mg} / \mathrm{g}$ ) (Table 3 ).

The adaptive response of plant cells is aimed at preventing the photodynamic destruction of chlorophyll. In general, the changes in the pigment content may be related to the two-phase nature of Thuja occidentalis reaction to atmospheric pollution:

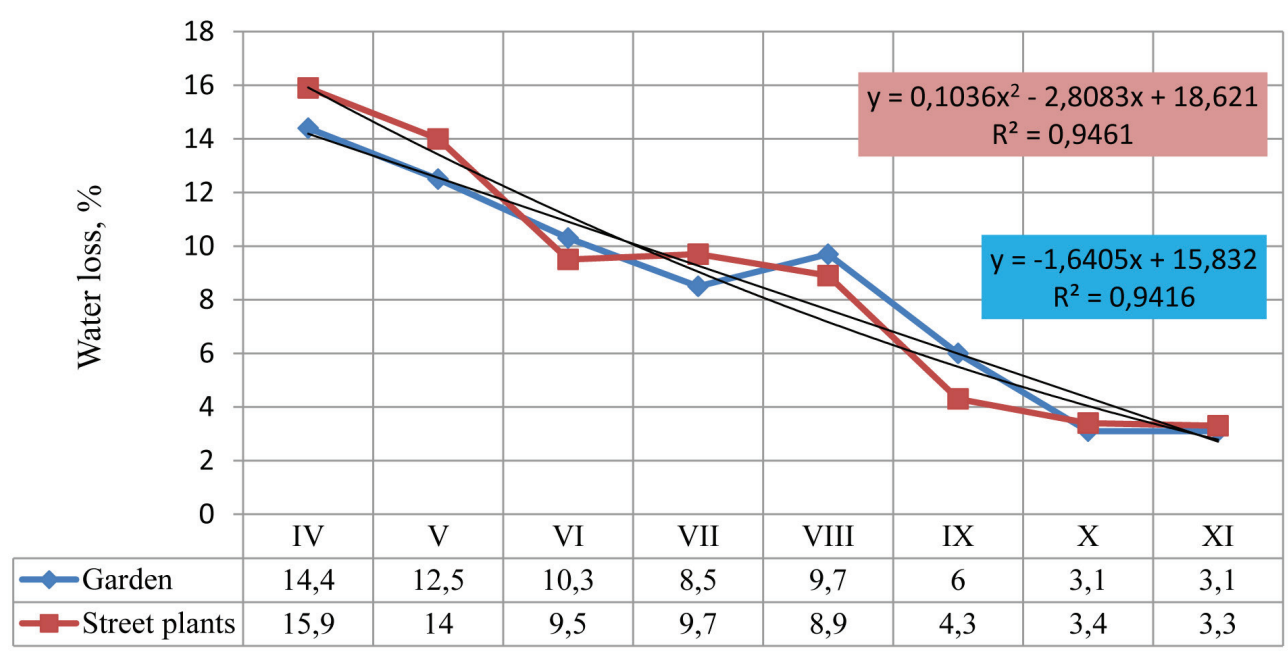

Fig. 2. Seasonal change in the water-holding capacity of Thuja occidentalis 'Smaragd' needles 


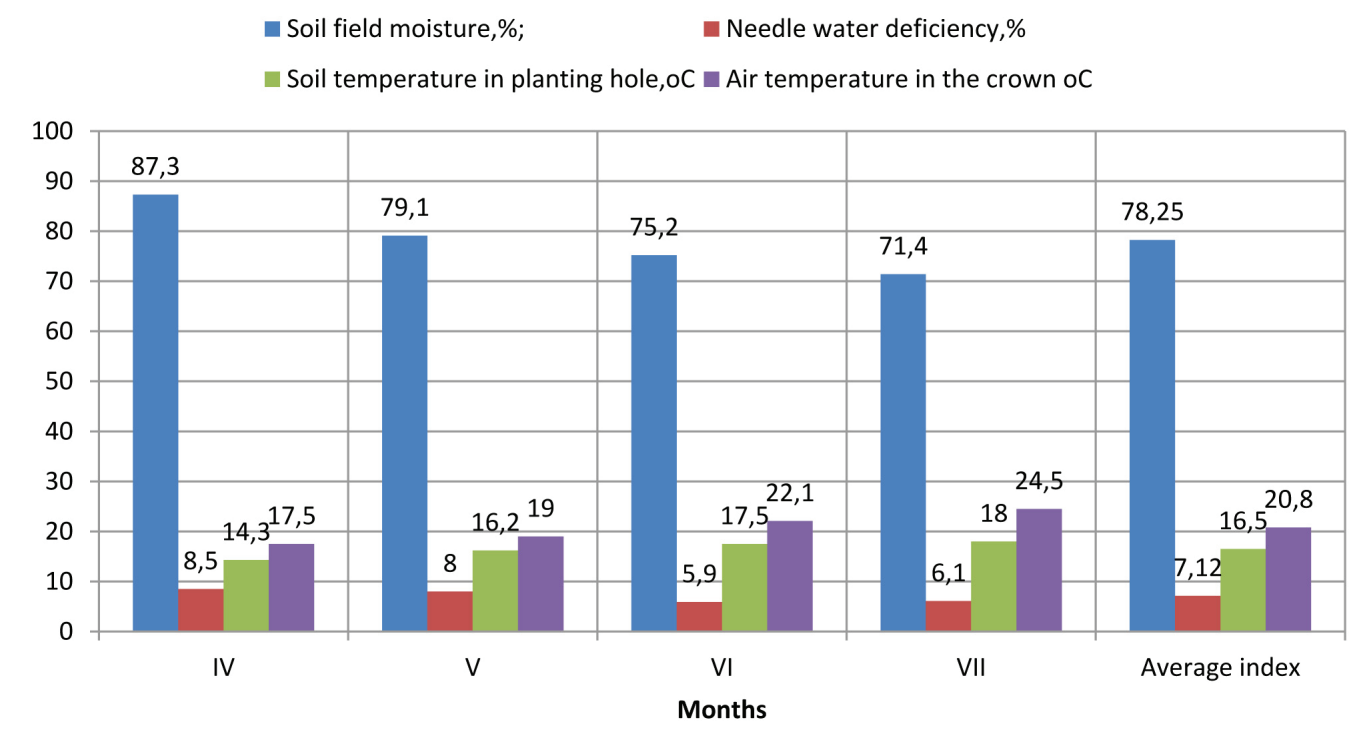

Fig. 3. Field moisture of the soil and water shortage in Thuja occidentalis 'Smaragd' needles in the public garden planting

Table 3. The content of pigments in the needles of Thuja occidentalis 'Smaragd' of its ornamental forms in different growth conditions

\begin{tabular}{|c|c|c|c|c|c|c|}
\hline Location & $\begin{array}{c}\text { Chlorophyll } a, \\
\mathrm{mg} / \mathrm{g}\end{array}$ & $\begin{array}{c}\text { Chlorophyll } \\
b, \mathrm{mg} / \mathrm{g}\end{array}$ & $\begin{array}{c}\text { Chlorophyll a / } \\
\text { Chlorophyll } b\end{array}$ & $\begin{array}{c}\text { Carotenoids, } \\
\mathrm{mg} / \mathrm{g}\end{array}$ & $\begin{array}{c}\text { The sum of } \\
\text { chlorophylls } a+b\end{array}$ & $\begin{array}{c}\text { Chlorophylls / } \\
\text { Carotenoids }\end{array}$ \\
\hline Public garden & 0.73 & 0.35 & 2.08 & 0.27 & 1.08 & 3.12 \\
\hline Street & 0.38 & 0.14 & 2.7 & 0.13 & 0.52 & 3.75 \\
\hline
\end{tabular}

in the first phase, the activity of functional adaptive reactions is increased, and in the second phase, the inhibition of metabolic processes is characteristic.

\section{Assessment of the physiological state of Thuja occidentalis 'Smaragd' needles by fluorescence}

The initial stages of photosynthesis in leaves or needles due to the action of environmental factors do not remain unchanged, but are actively regulated by the cell in accordance with its physiological state. The purpose of this regulation is to optimally coordinate the light and dark stages of photosynthesis necessary to maintain a certain level of metabolism in the changed environment.

The changes in the initial stages of photosynthesis are reflected in the changes in chlorophyll fluorescence in photosynthetic cell membranes. Absorption of a light quantum transfers the chlorophyll molecule into an electric excited state, the energy of which in the solution in the absence of photosynthesis is transformed either to heat or to fluorescence. In a photosynthetic membrane, the energy of electronic excitation of chlorophyll is used in reaction centers to generate an electron flow at the initial stage of photosynthesis necessary for the restoration of ATP and NADP.

The results of the studies show that the maximum value of the vitality index (0.64) belongs to a plant that grows under optimal conditions of the garden (5 points), while in the Yefremov street, where the environmental conditions are worse, $R_{f d}=0.33$, i.e. 3 points.

Adverse environmental conditions negatively affect the photosynthetic process, causing disturbances in the state of photosynthetic membranes and the transfer of reaction centers to an inactive (closed) state, which leads to a cessation of electron flow and an increase in fluorescence.

Table 4. Fluorescence indices of photosynthesis of Th.oc. 'Smaragd' needles

\begin{tabular}{|l|c|c|c|c|}
\hline \multirow{2}{*}{ Location of the study object } & \multirow{2}{*}{$\begin{array}{c}\text { Assessment of growth } \\
\text { conditions, points } \\
\text { (on a five-point scale) }\end{array}$} & \multicolumn{2}{|c|}{ Fluorescence indexes } & \multirow{2}{*}{$\begin{array}{c}\text { Vitality index, } \\
R_{f d}\end{array}$} \\
\cline { 3 - 5 } & 3 & 20 & 30 & 0.33 \\
\hline Yefremov street & 5 & 12 & 34 & 0.64 \\
\hline Public garden & & & Maximum, $F_{m}$ & \\
\hline
\end{tabular}




\section{CONCLUSIONS}

The analyzed proportionality of the morphological and physiological states of Thuja occidentalis 'Smaragd' planting suggests that they are interrelated and may collectively reflect the assessment of plant vitality. Especially useful are the methods of express analysis, in particular when determining the temperature gradients and determining the viability index by fluorescence indices.

Under the conditions of street planting with its positive temperature gradient (soil temperature is higher than the air temperature in the crown), Thuja occidentalis 'Smaragd' undergoes a decrease in the growth of apical and side shoots during the summer months, and overall, the plant vitality is weakened, which is manifested in a deterioration of the water regime of the plants.

Our studies and the results obtained have revealed the peculiar "islands of heat" in which the plants are located. The horizontal temperature gradient made it possible to reveal a phenomenon such as a shift in the growth conditions, that is, sort of a shift from typical natural conditions of Thuja occidentalis 'Smaragd' range, in a southerly direction, i.e. warmer, drier. The high abundance of seeds of suppressed and strongly suppressed plants under these adverse conditions is explained by the adjustment of the adaptive mechanism of the plants for accelerated reproduction. The protective adaptive response is manifested in the increase of the needles of the suppressed and strongly suppressed plants.

\section{REFERENCES}

1. Kycheryavyj V.P., Popovych V.V., Kycheryavyj V. S. 2018. The climate of a large city and ecocline ordination of its vegetation cover. J. Geogr. Inst. Cvijic, 68(2), 177-193. https://doi.org/10.2298/ IJGI1802177K

2. Bessonova V.P., 2006: Workshop on plant physiology. Dnepropetrovsk. RVV DDAU, 316 pp.

3. Kapustyanyk,V.B.; Mokryi, V.I., 2004: Opticalspectral methods in scientific and technical examination. Workshop. Lviv. Ivan Franko LNU Press, 206 pp. (in Ukrainian)

4. Kycheryavyi, V.P. 2001. Urboecology. Lviv-World, Lviv (in Ukrainian)

5. Kycheryavyi V.S. 2015. Eastern arbovitae and its ornamental forms in the landscaping of Lviv. Abstract of the dissertation. PhD in Agr.Sc., 20 pp. (in Ukrainian)

6. Kycheryavyi V.S. 2012. Assessment of the physiological state of Thuja occidentalis L. needles by fluorescence analysis. International readings dedicated to the 110th anniversary of the birth of Prof. L.I. Rubtsov, DBISc. Mater., Kyiv, 311-314. (in Ukrainian)

7. Radchenko S.I. 1966. Temperature gradients of the environment and plants. M.-L. Nauka., 398 pp. (in Russian]

8. Rudyshyn R.D., Kuryata V.G. 2004. Workshop on the basics of general ecology. Vinnytsa: Vinnytsa International University of Development, $101 \mathrm{pp}$. (in Ukrainian)

9. Sarbaeva E.V., Voskresenskaya O.L., Zhukova L.A. 2002. Ontogenesis of eastern arborvitae. Ontogenetic atlas of medicinal plants. MarGU: YoshkarOla, 3, 25-28. (in Russian) 